\title{
The information content of dividends on the Johannesburg Stock Exchange: An empirical analysis
}

\author{
L.L. Ooms, A.A. Archer* and E. van der M. Smit \\ University of Stellenbosch Business School, P.O. Box 610, Bellville, 7535 Republic of South Africa
}

Received 5 February 1987; accepted 18 June 1987

\begin{abstract}
The authors attempt to make a contribution to the research into the validity of the efficient market hypothesis on the Johannesburg Stock Exchange by investigating the market's reaction to dividend announcements. Evidence is presented that the efficient market hypothesis is not invalidated as traders on dividend information are not able to generate returns which are significantly different from the return generated by the market portfolio. It seems that the market is not sophisticated enough to distinguish between good and bad news as both portfolios yield either positive or negative abnormal returns. In quite a few cases investors holding a bad news portfolio were better off than holders of a good news portfolio. These facts suggest that the market is probably not reacting to dividend information but to the underlying earnings information which is simultaneously released. These results were obtained by applying the conventional techniques for announcement studies and it is obvious that this methodology should be refined and improved and further adapted to local practices in order to be able to give conclusive answers.
\end{abstract}

Die outeurs poog om 'n bydrae tot die navorsing oor die geldigheid van die doeltreffendemark-hipotese soos toegepas op die Johannesburgse Effektebeurs te maak deur die mark se reaksie op dividendaankondigings te ondersoek. Daar word bewys gelewer dat die doeltreffendemark-hipotese nie ongeldig is nie, aangesien handelaars wat aan die hand van dividendinligting optree nie opbrengste verdien wat beduidend verskil van die markopbrengs nie. Dit blyk dat die mark nie gesofistikeerd genoeg is om tussen goeie en slegte nuus te onderskei nie, aangesien albei portefeuljes of positiewe of negatiewe abnormale opbrengste oplewer. In 'n hele aantal gevalle was beleggers wat 'n slegtenuus-portefeulje gehou het beter daaraan toe as die houers van goeienuus-portefeuljes. Dit blyk dus dat die mark waarskynlik nie op dividendinligting reageer nie, maar op die onderliggende verdienste-inligting wat terselfdertyd bekend gemaak word. Hierdie resultate is verkry deur van die konvensionele tegnieke vir aankondigingstudies gebruik te maak en dit is duidelik dat die metodologie verfyn, verbeter en verder by plaaslike praktyke aangepas moet word om afdoende bewyse te vind.

- To whom correspondence should be addressed

\section{Introduction}

In recent years a major controversy has formed in finance literature about the empirical evidence of the information content of dividends. Quite a few studies lend considerable support to the position of dividend non-triviality, while on the other hand the work by Watts (1973) for example, presents evidence of the triviality of dividends. In South Africa work by Knight \& AffleckGraves (1984) seems to support Watt's thesis.

Because of the close proximity of companies' earnings and dividend announcement dates, the dispute has centered on the identification and control of contemporaneous earnings information.

Research into the information content of dividends is part of the efficient market hypothesis research. This hypothesis posits that the market provides accurate signals for resource allocations - i.e. a market in which firms can make investment decisions and investors can choose among the securities that represent ownership of companies under the assumption that security prices which at any time 'fully reflect' all available information is called 'efficient' (Fama, 1970: 383).

The primary purpese of this study is to offer further evidence about the validity of the efficient market hypothesis on the Johannesburg Stock Exchange (JSE) by estimating the speed and accuracy with which market prices react to dividend announcements. The results of this study may confirm or invalidate Knight's (1983) conclusions about the information content of earnings.

\section{The hypotheses}

The share price of a company can be defined as the expected value of future cash flows. Changes in share prices can be understood as being the result of changing expectations. If dividends have information value, the information contained in the dividend announcement must be able to change the assessed probability distribution of future cash flows. In other words, if dividends have information value, it should find expression in abnormal share price performance around the announcement date. Therefore, the central hypothesis tested can be worded as:

$\mathrm{H}_{0}$ : the abnormal return generated by a share for which a dividend was announced is not significantly different from zero for the period spanning the announcement date, against:

$\mathrm{H}_{1}$ : the abnormal return generated by a share for which a dividend was announced is significantly different from zero for the period spanning the annoucement date.

The null hypothesis states that the market expectations are not altered by the information conveyed to the market by means of a dividend announcement, while the alternative hypothesis posits that dividend announcements do change market expectations. 
In addition to the above hypothesis, it will also be tested whether the market is able to differentiate among the size of dividend changes in the sense that larger dividend changes result in high abnormal returns. The hypothesis to be tested is:

$\mathbf{H}_{\mathbf{0}}$ : the abnormal return for a share for which a larger dividend change was announced is not significantly different from the abnormal return of a share for which a smaller dividend change was announced, against:

$\mathbf{H}_{1}$ : the abnormal return for a share for which a larger dividend change was announced is significantly larger than the abnormal return generated by a share for which a smaller dividend change was announced.

A two-stage regression approach was applied in order to determine the incremental information content of dividends over earnings and vice versa.

\section{Research design}

\section{Sampling procedure}

The initial population consisted of all companies listed in the Industrial Section of the JSE that declared a yearly dividend over the period 1 January 1973 - 31 December 1984. Companies that did not pay out a dividend each year were excluded from the analysis because the FamaBabiak (FB) model, which was used for predicting expected dividend changes, contains lagged variables. It is therefore imperative that an uninterrupted datafile is available. Moreover, multiple regression with nonsynchronous data may cause the ordinary least squares estimators of the regression coefficients to be biased and inconsistent.

Extraordinary dividend announcements were excluded from the sample as the underlying event has nothing to do with the normal range of activities of a company.

Simple random sampling was applied with the result that each dividend announcement in the population had an equal chance of being chosen. Stratified random sampling was considered but rejected as the criteria for stratifying the population were not obvious. Stratified sampling requires strata characterized by homogeneous income and dividend data. As the data are collected over a considerable period of time, it is questionable whether those strata remain homogeneous over time.

A sample was drawn from a population of 1122 dividend announcements during the period 1 January 1980 - 31 December 1984. The dividend data for the period 1 January 1973 - 31 December 1979 were used for estimating the FB regression parameters. The final sample consisted of 190 dividend announcements for 143 different companies. This means that $55 \%$ of all shares listed in the Industrial Section of the JSE and $17 \%$ of all dividend announcements in the population are included in the sample.

\section{Price-relative returns and market returns}

Price-relative returns were calculated by means of the following formula:
$R_{i, t}=\frac{P_{i, t}-P_{i, t-1}+\mathrm{DIV}_{i, t}+\mathrm{ED}_{i, t}}{P_{i, t-1}}$

where $R_{i, t}=$ ex post return on share $i$ over period $t ; P_{i, t}$ $=$ closing price of share $i$ at the end of period $t ; P_{i, t-1}=$ opening price of share $i$ at the beginning of period $t$; $D I V_{i, t}=$ adjusted dividend for share $i$ over period $t$; $E D_{i, t}=$ equivalent dividend for share $i$ at the end of period $t$.

Equivalent dividends are needed for calculating correct relative price returns that take into account changes in the capital structure of a particular company such as capitalization issues, share splits, share consolidations and rights issues. In this respect the interested reader is referred to the work done by de Villiers (1980: 61-72) and du Plessis (1984: 67-73). Adjusted dividends and EPS figures were calculated in order to make figures of different years comparable.

The market return consists of a price-relative return and a dividend yield on the market portfolio for a particular period of time and is defined as:

$R_{m, t}=\frac{P I_{i, t}-P I_{m, t-1}}{P I_{m, t-1}}+\frac{D I_{m, t} \times n}{100 \times 365}$

where $R_{m, t}=$ ex post return on the market portfolio over period $t ; P I_{m, t}=$ market price index value at the end of period $t ; P I_{m, t-1}=$ market price index value at the beginning of period $t ; D I_{m, t}=$ dividend index for the market portfolio at the end of period $t$ in percentage terms; $n=$ number of days between the end of period $t$ and the end of period $t-1$.

The market indices used in this study are the JSE Actuaries Industrial Index (capitalization index) and the JSE Actuaries Dividend Index. Both indices were retrieved from the University of Stellenbosch Graduate School of Business (USB) financial databank.

\section{The market model}

As information content studies are concerned with information variables that relate to an individual company, overall market effects have to be eliminated from price-relative returns and these returns have to be adjusted for the risk level of a particular share. The model widely used for calculating residuals of riskadjusted abnormal performance is the market model. Mathematically the model is of the following form:

$R_{i, t}=\alpha_{i}+\beta_{i} R_{m, t}+\epsilon_{i, t}$

where $\alpha_{i}=$ intercept of the regression line for company $i ; \beta_{i}=$ slope of the regression line for company $i$ which is a proxy for the risk level the share has to bear; $\epsilon_{i, t}=$ residual return for share $i$ in period $t$ which is a proxy for the abnormal performance of share $i$ in period $t$.

The model is not supported by any theory: it simply postulates a linear relationship between the return on a security and the return on the market. In order to determine the equilibrium return the regression is run 
between $R_{i, t}$ and $R_{m, t}$ for a period which is different from the period under examination. The assumption underlying this method is that the slope and intercept term are constant over time. Abnormal return is thus defined as:

$\mathbf{e}_{i, t}=\boldsymbol{R}_{i, \ell}-\left(\hat{\alpha}_{i}+\hat{\boldsymbol{\beta}}_{i} \boldsymbol{R}_{m, t}\right)$

where all symbols are as defined before.

However, some difficulties may arise with the application of the market model.

Returns are not normally distributed; instead they are distributed symmetrically, but the empirical distribution has tails which are heavier than those of the normal distribution. However, as long as the distribution is symmetrical, the least squares estimators are unbiased and consistent, although inefficient (Raes, 1984: 13).

As already mentioned, the coefficients of the market model are estimated for a period different from the period under examination. In this respect both the choice of the benchmark period and the interval over which the returns are calculated are interesting issues. Concerning the interval, Boshoff (in Affleck-Graves 1983: 29) found that different return intervals yielded different betas and that shares were ranked differently in terms of risk depending on the interval used. After some experimental runs it was decided to use a biweekly interval and estimation period two years before and two years following the examination period, i.e. 31 weeks around the announcement week. This implies that approximately 104 data pairs were obtained for the estimation of market model coefficients.

The estimation of market model coefficients may be subject to bias which is attributable to the phenomenon of thin trading for quite a few shares in the sample. Scholes \& Williams (1977) and Dimson (1979) dealt extensively with the problem of beta-estimation from non-synchronous data. Scholes \& Williams (1977: 310) report that in the particular case of non-synchronous trading both alphas and betas are biased and inconsistent. Securities trading very frequently or infrequently on the average have ordinary least squares estimators asymptotically biased upward for alphas and downward for betas.

Neither Dimson's Aggregated Coefficients Method nor Scholes \& Williams' methodology is applied for adjusting the market model coefficients, the main reason being that the data required for calculating adjusted betas were not available at the time the research was done. Instead a more drastic way of dealing with the problem of overestimated alphas and underestimated betas was followed. It was assumed that the limit value for an adjusted beta equals one and that the limit value for an unbiased alpha equals zero. In other words, abnormal returns are measured as the difference between the actual share return for a particular period and the market return for the same period:

$$
\begin{aligned}
e_{i, t} & =R_{i, t}-\left(\hat{\alpha}_{i}+\hat{\beta}_{i} R_{m, t}\right) \\
& =R_{i, t}-\left(0+1 R_{m, t}\right) \\
& =R_{i, t}-R_{m, t}
\end{aligned}
$$

It is clear that the abnormal return defined by formula (5) is not adjusted for risk. For each portfolio that will be formed two Cumulative Abnormal Return $(C A R)$ values will be calculated: one risk-adjusted $C A R$ and a $C A R$ not adjusted for risk.

\section{Cumulative Abnormal Returns}

A major concern in an event study is to assess the extent to which the share price performance around announcement has been abnormal, i.e. the extent to which the share returns were different from the equilibrium return as predicted by the market model.

For each time period an average residual for period $t$ can be calculated over the total number of dividend announcements in the sample:

$A R_{t}=\sum_{i=1}^{n} \frac{\mathrm{e}_{i, t}}{n}$

where $A R_{t}=$ average abnormal (residual) return for period $t$, relative to the announcement week; $n=$ number of shares/announcements for which an abnormal return could be calculated in period $t$ and all other symbols are as defined before.

In order to be able to draw meaningful conclusions, it should be tested whether each $A R_{t}$ value is significantly different from zero or not. To do this a $t$ test was constructed and it was assumed that the average returns are drawings from an approximate normal distribution:

$t_{A R_{\imath}}=\frac{A R_{t}}{s_{A R_{r}}}$

where $t_{A R_{t}}=$ test value for $A R_{t} ; s_{A R_{t}}=$ standard deviation of $A R_{t}$ and all other symbols are as defined before.

However, some problems arise with the calculation of the standard deviation $s_{A R}$. Jaffe (1974: 98) posits that the residuals of different shares in a given period are correlated, e.g. because they are in the same sector. The cross-sectional differences among the different shares induce dependencies over time in the $A R_{t}$ series. In order to take these dependencies into account, the $t$ test statistic should be adjusted.

The Crude Dependence Adjustment (Brown \& Warner, 1980: 251) was applied as it takes into account cross-sectional dependencies in the security-specific performance. The standard deviation of week $t$ average performance is estimated from the values of the average performance measures in weeks -35 through -16 relative to the announcement.

For estimating $s_{A R_{t}}$ the shares for which an abnormal return could be calculated were looked up and a portfolio containing the same shares was formed for each time period -35 through -16 . An $A R_{t}$ value was 
calculated for each period resulting in a set of $20 A R_{t}$ values. The standard deviation, with 19 degrees of freedom, is calculated from (Brown \& Warner, 1980: 251):

$S_{A R_{i}}=\left[\frac{1}{19}\left(\sum_{t=-35}^{-16}\left[\left(\frac{1}{n} \sum_{i=1}^{n} A R_{i, \ell}\right)-A^{*}\right]^{2}\right)\right]^{1 / 2}$

with

$A^{*}=\left[\sum_{t=-35}^{-16} \sum_{i=1}^{n} A R_{i, t}\right] \frac{1}{20 n}$

where all the symbols are as defined before.

The $t$ test statistic for abnormal performance in week 0 can be written as:

$t_{A R_{0}}=\frac{\frac{1}{n} \sum_{i=1}^{n} A R_{i, o}}{s_{A R_{i}}}$

The $t$ test statistic for abnormal performance in the $(-15,+15)$ interval equals:

$t_{A R_{r}}=\frac{\frac{1}{31 n} \sum_{t=-15}^{\sum} \sum_{i=1}^{\sum} A R_{i, t}}{s_{A R_{r}}}$

where all symbols are as defined before.

In order to get an idea about the performance during the period under consideration $C A R$ values were calculated from

$C A R_{t}=C A R_{t-1}+A R_{t}$

where all symbols are as defined before.

Examining the $C A R$ of a portfolio is a way of determining whether or not the values of the average residuals, starting from the week of cumulation, are systematically different from zero.

\section{Classification schemes of dividend information}

Classification schemes of dividend information can be distinguished in two main classes. On the one hand there are the so-called naive classification schemes implying that all dividend changes are unexpected. In this paper two different naive classification schemes will be used.

On the other side of the spectrum one finds the classification schemes that try to take into account market expectations. Here it is assumed that the market participants are more sophisticated and are able to assess market-related and company-specific information accurately. The FB dividend expectations model was used in this study.
Classification schemes based on Fama-Babiak residuals

Fama \& Babiak (1968: 1132-1161) studied the determinants of dividend payments by individual companies. They explained dividend cbanges in terms of earnings and past dividends. The FB-model is of the following form:

$$
\Delta D I V_{i, t}=\alpha_{i} D I V_{i, t-1}+\beta_{i} E P S_{i, t}+\gamma_{i} E P S_{i, t-1}+\epsilon_{i, t}
$$

where $\epsilon_{i, t}=$ error term which is a proxy for the unexpected change in dividends; $\alpha_{i}, \beta_{i}, \gamma_{i}=$ regression coefficients and all other symbols are as defined before.

The observed error term, $e_{i, t}$, is defined as

$e_{i, t}=\Delta D I V_{i, t}-\Delta D \hat{V}_{i, t}$

where $\Delta D I V_{i, t}=$ real change in dividends; $\Delta D N_{i, t}=$ change in dividends as predicted by the FB model.

Econometric theory assumes (Gujarati, 1978: 40) that the error term is uncorrelated with the explanatory variables. This implies that $\epsilon_{i, t}$ represents that element of dividend changes which is not explained by previous year's dividends and earnings and current earnings.

As the FB model was developed for explaining the determinants of dividend payments by individual companies, a time-series approach would seem appropriate. In this situation however, a time-series approach was not feasible because only six observations were available. Therefore it was decided to run the FB model on a sectoral basis. This cross-sectional approach allowed for a larger number of observations per regression relative to the traditional time-series approach.

The sector per sector regressions for 'Engineering' and 'Electronics' turned out to have insignificant $F$ values. Therefore it was decided to run an all-sector regression which was used for predicting unexpected dividend changes for companies in the 'Electronics' and 'Engineering' sectors.

According to the sign of the error term of the FB model, announcements are classified into 'good' and 'bad' news. There exists a probability of misclassification due to the inherent noise in the FB regression model. As suggested by Kwan (1981: 196), a remedial treatment for the noise problem was decided on by constructing a filter using a $95 \%$ prediction interval. If a particular $e_{i, t}$ value falls outside this prediction interval there is only a $2,5 \%$ probability that the announcement is misclassified.

\section{Classification scheme based on the size of the relative} dividend changes

A justification for a naive classification model is derived from the 'reluctance to change' assertation which states that managers do not change dividend payments when they have good reasons to expect a significant negative change in the future prospects of the company. Generally, a naive dividend expectations model is written as:

$D \Gamma V_{i, t}=D I V_{i, 1-1}$ 


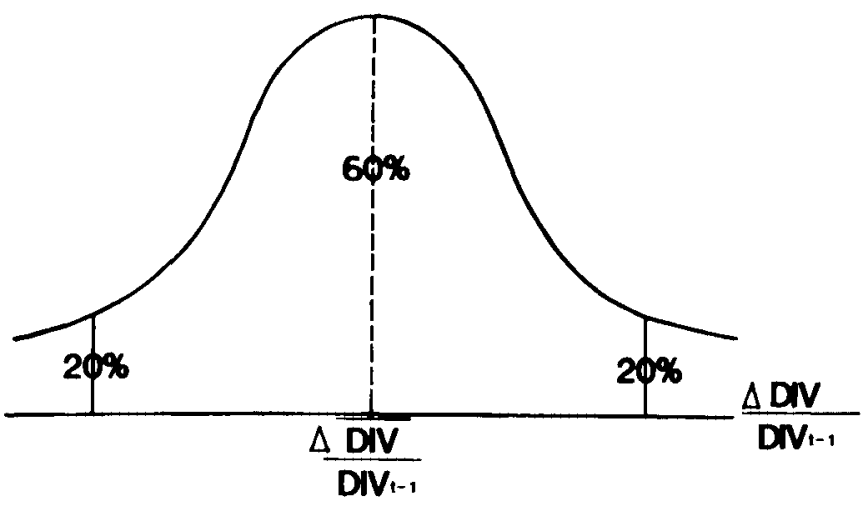

Figure 1 Classification scheme for relative dividend changes

An increase in dividends should signal a favourable change in management's expectations, whereas a decrease in dividends is likely to indicate a pessimistic view of the company's prospects.

Relative dividend changes were calculated in order to solve the scaling problems and those relative dividend changes were grouped per financial year. As shown in Figure 1, the relative dividend changes follow an approximate normal distribution. For each year upper and lower limits were calculated so that the lower $20 \%$ of relative dividend changes are considered as signalling bad news, the middle $60 \%$ are considered to represent normal, i.e. expected, information, while the upper $20 \%$ send good news to the market. Three different portfolios were formed, one set of portfolios for the all shares group, one set for the frequently traded shares and a set for the infrequently traded shares.

Classification scheme based on the relationship between relative changes in dividends and relative changes in EPS

Criticism can be passed on the naive classification scheme as it does not make any attempt to separate the potential confounding effects of dividends and earnings announcements. From the point of view of efficient market testing it is irrelevant whether abnormal returns could be generated by trading on earnings information, dividend information, or both. Any consistent abnormal return generated over a long period of time would lead to a rejection of the efficient market hypothesis. As this study deals with the information content of dividends, it is important to isolate the information effect of a dividend announcement from the earnings announcement effect. This is not easy as most dividend and earnings information is released simultaneously.

It was attempted to control the earnings information in a way suggested by Pettit (1972: 998-999), but unfortunately the resulting number of dividend announcements in each portfolio was insufficient to be able to draw statistically meaningful conclusions.

Instead a classification scheme based on the relationship between relative earnings changes and dividend changes was developed. Good news is said to be sent to the market if the relative changes in dividends are greater than the relative changes in EPS. It is assumed that if management is prepared to increase the dividend with a percentage which is higher than the EPS increase, it is a signal that management is confident about the future prospects of the company and that management expects earnings to continue to increase in the coming years. Bad news is sent to the market if the relative change in dividends is smaller than the relative change in earnings.

\section{Two-stage regression analysis}

Attention was already drawn to the fact that it is very difficult to separate the confounding information effects of dividends and earnings as both pieces of information are released simultaneously. Therefore it was decided that another research perspective, different from the $C A R$ approach, would be appropriate for assessing the informational content of dividends. In theory a twostage regression approach permits the determination of the incremental explanatory power of dividends over earnings and vice versa (Beaver, Griffin \& Landsman, 1982: 27).

The following procedure was applied for determining the incremental information content of dividends conditional upon the knowledge of earnings:

1. The annual change in dividends for company $i$ during year $t$ was regressed on the annual change in earnings for the same company $i$ and year $t$ in order to isolate the regression residual $z \Delta D I V_{i, t}$, which is by construction uncorrelated with the annual change in earnings:

$\Delta D I V_{i, t}=\alpha_{i}+\beta_{i} \Delta E P S_{i, t}+z \Delta D I V_{i, t}$

where $z \Delta D I V_{i, t}=$ regression residual, i.e. that part of the change in dividends which is not explained by the change in earnings; $\alpha_{i}, \beta_{i}=$ regression parameters and all other symbols are as defined before.

2. Different measures for returns are regressed on the change in earnings for company $i$ during financial year $t$ and on the residual term of regression (16).

$\operatorname{Return}_{i, t}=\alpha_{i}+\beta_{i} \Delta E P S_{i, t}+\gamma_{1 i} z \Delta D I V_{i, t}+\epsilon_{i, t}$

where the respective returns are $P_{i, t}=$ price return for company $i$ during the week of the announcement; $C A R_{i, t}$ $=C A R$ cumulated from week -2 through +2 for company $i$. The residual return is calculated by means of the market model coefficients; XCAR $R_{i, \ell}=C A R$ cumulated from week -2 through +2 for company $i$. The residual is calculated under the assumption that alpha $=$ 0 and beta $=1 ; \epsilon_{i, 1}=$ random disturbance variable.

If dividends contain information which is not provided by earnings, the regression coefficient $\gamma_{1 i}$ should be significantly different from zero. A $t$ test is used for determining whether $\gamma_{1 i}$ is significantly different from zero or not.

The dividends and earnings variables are highly correlated and it is quite plausible to assume that dividends and earnings possess a considerable amount of common explanatory power with respect to share returns, which implies that the explanatory variables 
might not be mutually exclusive in terms of information value. Therefore the two-stage regression model was reversed and run in the opposite direction.

The procedure for determining the incremental information content of earnings conditional upon the knowledge of dividends is identical to the one described before.

First stage:

$\Delta E P S_{i, t}=\alpha_{i}+\beta_{i} \Delta D I V_{i, t}+z \Delta E P S_{i, t}$

where $z \Delta E P S_{i, t}=$ residual regression term, i.e. that part of the change in earnings for company $i$ and financial year $t$ which is not explained by the change in dividends for company $i$ and year $t$ and all other symbols are as defined before.

Second stage:

$\operatorname{Return}_{i, t}=\alpha_{i}+\beta_{i} \Delta D I V_{i, t}+\gamma_{2 i} z \Delta E P S_{i, t}+\epsilon_{i, t}$

Table 1 Summary of conclusions to be drawn from the two-stage regression analysis

\begin{tabular}{|c|c|c|}
\hline$\gamma_{1}$ value & $\gamma_{2}$ value & Conclusion \\
\hline Significant & Insignificant & $\begin{array}{l}\text { Incremental information of } \\
\text { dividends over earnings }\end{array}$ \\
\hline Insignificant & Significant & $\begin{array}{l}\text { Incremental information of } \\
\text { earnings over dividends }\end{array}$ \\
\hline Significant & Significant & $\begin{array}{l}\text { Dividends and earnings are } \\
\text { surrogates in terms of } \\
\text { informational value }\end{array}$ \\
\hline Insignificant & Insignificant & $\begin{array}{l}\text { Dividends and earnings infor- } \\
\text { mation is trivial or inadequate } \\
\text { channels for communicating } \\
\text { information to investors }\end{array}$ \\
\hline
\end{tabular}

where all the symbols are as defined before.

If earnings contain information which is not provided by dividends, the regression coefficient $\gamma_{2 i}$ should be significantly different from zero which is decided on by means of a $t$ test.

Table 1 summarizes the conclusions that can be drawn from the two-stage regression analysis.

\section{Research findings}

\section{$C A R$ approach}

Table 2 lists the characteristics of the portfolios used for the $C A R$ analysis. In order to evaluate the performance of each portfolio the following tests were applied:

- significance test for the abnormal returns generated by the different portfolios;

- Cox-Stuart (Daniel, 1978: 58-62) test for detecting trends in the CAR series;

- Jonckheere-Terpstra (Daniel, 1978: 207) test for detecting significant differences in $C A R$ performance between 'good news' and 'bad news' portfolios.

\section{FB classification scheme}

The results in panel $A$ of Table 3 indicate that holders of companies that declared a higher than expected dividend earned only returns that are lower than the returns that would have been earned by investors holding the market portfolio. Results in panel B demonstrate that holders of companies declaring a lower than expected dividend earned less than the holders of the market portfolio. It should be noted that the results reported in panel $B$ are not significantly different from zero.

The results reported in panel $\mathrm{C}$ and $\mathrm{D}$ show a positive abnormal return for both the good news and the bad news portfolio, but the return generated by the good news portfolio over 31 weeks is lower than the return generated by the bad news portfolio over the same period.

Table 2 Portfolios used for the CAR analysis

\begin{tabular}{llll}
\hline Portfolio & Message & Classification scheme & Trading characteristics \\
\hline 1.1 & Good news & Positive FB residuals & All shares \\
1.2 & Bad news & Negative FB residuals & All shares \\
2.1 & Good news & Positive FB residuals & Frequently traded shares \\
2.2 & Bad news & Negative FB residuals & Frequently traded shares \\
3.1 & Good news & Positive FB residuals & Thinly tradeed shares \\
3.2 & Bad news & Negative FB residuals & Thinly traded shares \\
4.1 & Bad news & Small dividend changes & All shares \\
4.2 & Normal news & Normal dividend changes & All shares \\
4.3 & Good news & Large dividend changes & All changes \\
5.1 & Bad news & Small dividend changes & Frequently traded shares \\
5.2 & Normal news & Normal dividend changes & Frequently traded shares \\
5.3 & Good news & Large dividend changes & Frequently traded shares \\
6.1 & Bad news & Small dividend changes & Thinly traded shares \\
6.2 & Normal news & Normal dividend changes & Thinly traded shares \\
6.3 & Good news & Large dividend changes & Thinly traded shares \\
7.1 & Good news & $\Delta D I V I D I V>\Delta E P S / E P S$ & All shares \\
7.2 & Bad news & $\Delta D I V I D I V<\Delta E P S I E S$ & All shares \\
\hline & & &
\end{tabular}


Table 3 All shares - Fama-Babiak residuals

\begin{tabular}{|c|c|c|c|}
\hline Period & Trend & $C A R$ & ICAR \\
\hline \multicolumn{4}{|c|}{ A.Portfolio 1.1: Good news market model $-\mathrm{df}=60$} \\
\hline$-15,+15$ & Down ${ }^{b}$ & $-7,48 \%$ c & $-3,0860$ \\
\hline$-10,+10$ & No & $-5,72 \% c$ & $-2,5637$ \\
\hline$-5,+5$ & No & $-3,48 \%$ c & $-2,4097$ \\
\hline$-15, \quad 0$ & Down ${ }^{b}$ & $-6,43 \% c$ & $-3,6901$ \\
\hline $0,+15$ & No & $-1,05 \%$ & $-0,6046$ \\
\hline \multicolumn{4}{|c|}{ B.Portfolio 1.2: Bad news market model $-\mathrm{df}=40$} \\
\hline$-15,+15$ & No & $-3,93 \%$ & $-0,9103$ \\
\hline$-10,+10$ & No & $-4,85 \%$ & $-1,3671$ \\
\hline$-5,+5$ & No & $-0,82 \%$ & $-0,3206$ \\
\hline$-15, \quad 0$ & Down & $-3,68 \%$ & $-1,1858$ \\
\hline $0,+15$ & $\mathbf{U p}^{\mathrm{b}}$ & $0,21 \%$ & 0,0685 \\
\hline \multicolumn{4}{|c|}{ C.Portfolio X.1.1: Good news - alpha $=0$, beta $=1-$ df $=60$} \\
\hline$-15,+15$ & $U p^{b}$ & $9,16 \%$ & 3,7992 \\
\hline$-10,+10$ & $\mathbf{U p}^{\mathrm{b}}$ & $5,61 \%$ & 2,8266 \\
\hline$-5,+5$ & $\mathbf{U p}^{\mathbf{b}}$ & $2,61 \%^{\mathrm{a}}$ & 1,8167 \\
\hline$-15, \quad 0$ & $U_{p} p^{b}$ & $1,53 \%$ & 0,8896 \\
\hline $0,+15$ & $U_{p}^{b}$ & $7,62 \% \mathrm{c}$ & 4,4013 \\
\hline \multicolumn{4}{|c|}{ D.Portfolio X.1.2: Bad news - alpha $=0$, beta $=1-\mathrm{df}=40$} \\
\hline$-15,+15$ & $\mathbf{U p}^{\mathrm{b}}$ & $9,46 \%$ & 1,8282 \\
\hline$-10,+10$ & $U p^{b}$ & $3,78 \%$ & 0,8896 \\
\hline$-5,+5$ & $U p^{b}$ & $4,49 \%^{c}$ & 3,4572 \\
\hline $\begin{array}{ll}-15, & 0\end{array}$ & No & $2,67 \%$ & 0,7196 \\
\hline $0,+15$ & $U_{p}^{b}$ & $6,78 \%^{\mathrm{a}}$ & 1,8251 \\
\hline Portfolio & \multicolumn{2}{|c|}{$J^{*}$ value } & esult \\
\hline
\end{tabular}

E.Jonckheere-Terpstra test

\begin{tabular}{|c|c|c|}
\hline 2 & $2,95^{b}$ & $C A R 1.1 \leqslant C A R 1.2$ \\
\hline $.1 .1-X .1 .2$ & $-0,58$ & $C A R \times .1 .1=$ \\
\hline
\end{tabular}

a Significant at 0,10 level; ${ }^{b}$ Significant at 0,05 level;

c Significant at 0,025 level

From Figure 2 it can be deduced that the downward CAR-trend in the weeks before the announcement is reversed for both portfolios. This implies that the market anticipates the announcement quite late, but that the market is not sophisticated enough to distinguish between good and bad news. From Figure 3 it is deduced that the market anticipates good news earlier than bad news in the case of the $X$ portfolios (CAR's are calculated under the assumption that alpha $=0$ and beta $=1$ ).

Panel $E$ indicates that the market does not seem to be able to distinguish between good and bad news or is not able to assess good and bad news in the right way. The trend analysis illustrates that the downward trend, existing before the announcement, is either reversed or comes to a halt with the announcement. The market is responding to the announcement, but investors react in the same direction to both good news as well as bad news.

Careful analysis of Figures 2 and 3 shows that there is a significant difference in the $C A R$ patterns between the market model portfolios and the $X$ portfolios. The

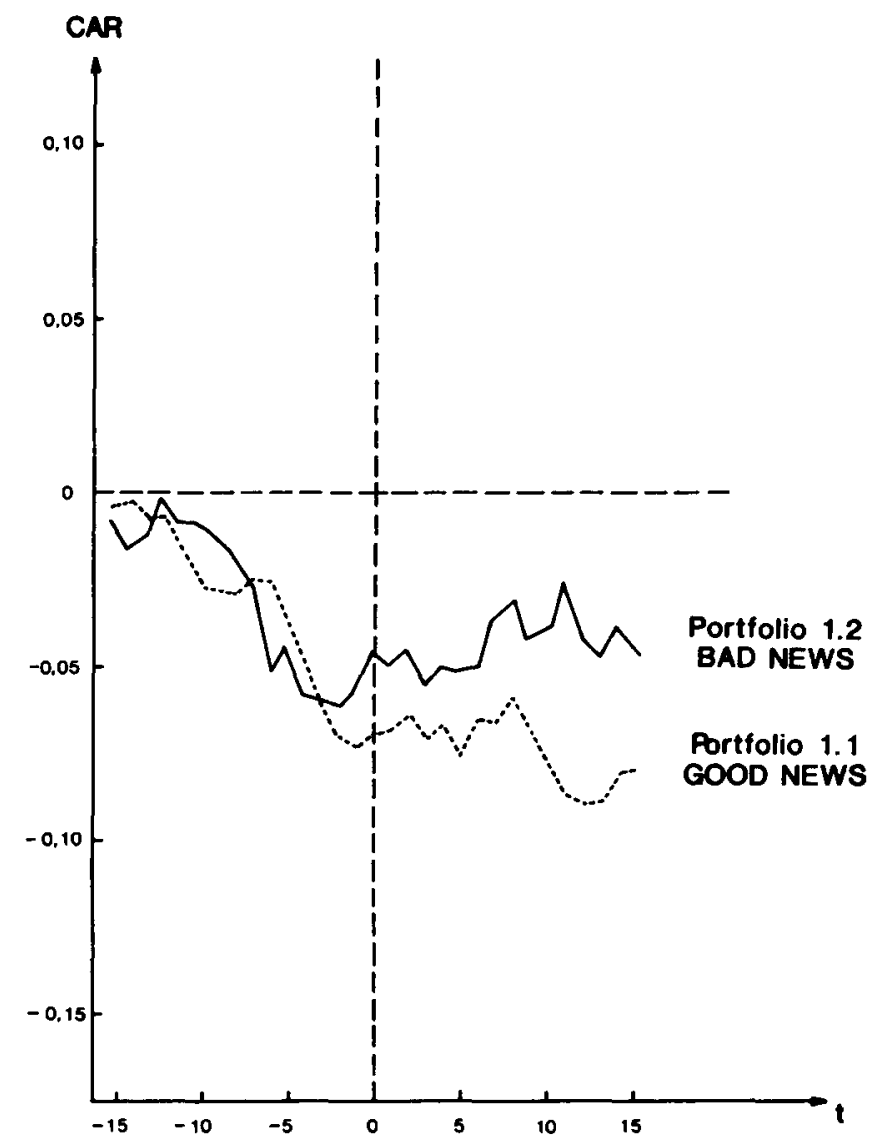

Figure 2 CAR graph - all shares - market model - FamaBabiak residuals

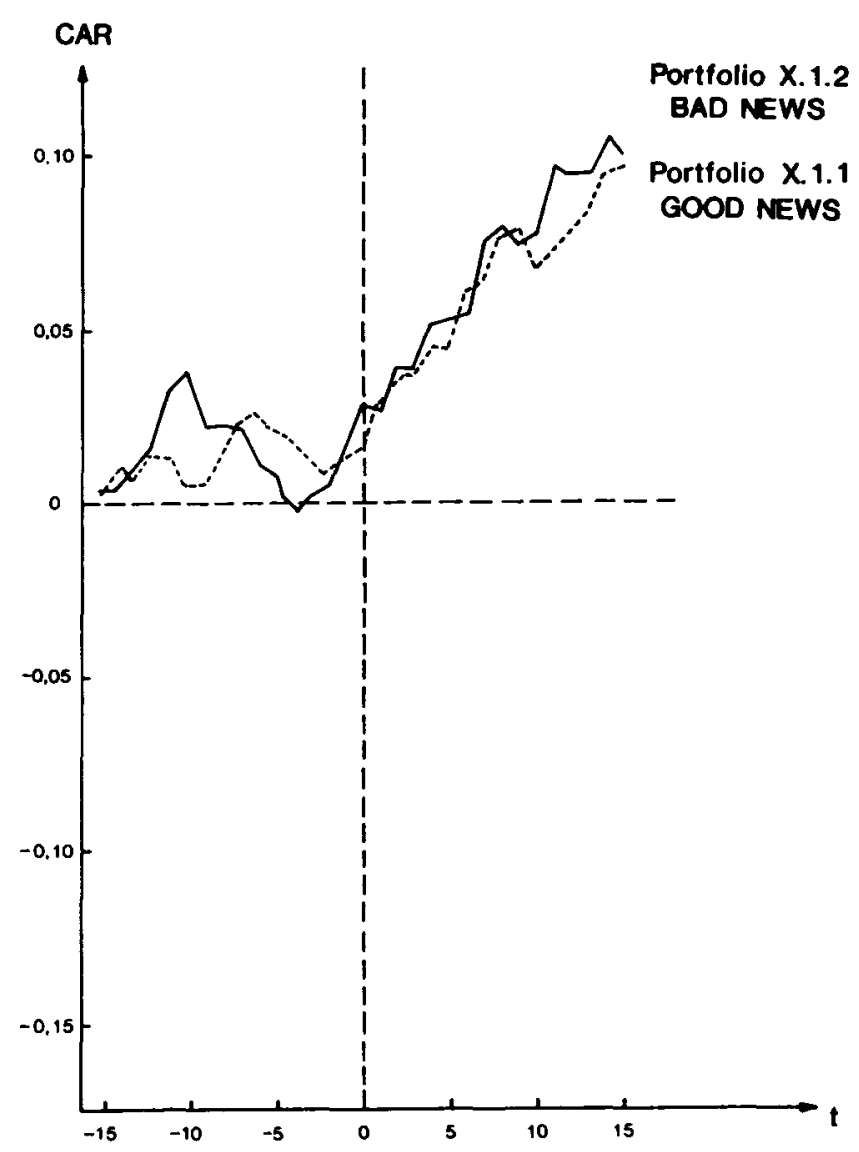

Figure $3 C A R$ graph - all shares - alpha $=0$, beta $=1-$ Fama-Babiak residuals 
Table 4 Naive classification scheme

\begin{tabular}{|c|c|c|c|c|c|c|c|c|c|}
\hline \multirow{2}{*}{$\begin{array}{l}\text { Market model } \\
\text { Period }\end{array}$} & \multicolumn{3}{|c|}{ Lower dividend changes 4.1} & \multicolumn{3}{|c|}{ Normal dividend changes 4.2} & \multicolumn{3}{|c|}{ Higher dividend changes 4.3} \\
\hline & Trend & $C A R$ & ICAR & Trend & $C A R$ & $t C A R$ & Trend & $C A R$ & I CAR \\
\hline$-15,+15$ & Down ${ }^{\circ}$ & $-2,95 \%$ & $-0,6157$ & No & $-1,79 \%$ & $-0,5389$ & Down $^{b}$ & $-12,69 \% c$ & $-4,2788$ \\
\hline$-10,+10$ & Down ${ }^{\circ}$ & $-2,95 \%$ & $-0,2303$ & No & $-0,07 \%$ & $-0,0265$ & No & $-9,84 \% \mathrm{c}$ & $-4,0329$ \\
\hline$-5,+5$ & Down & $-4,60 \%$ & $-1,6133$ & No & $0,27 \%$ & 0,1360 & No & $-2,99 \%$ & $-1,6944$ \\
\hline$-15, \quad 0$ & Down ${ }^{b}$ & $-3,34 \%$ & $-1,0061$ & Down & $-2,40 \%$ & $-1,0060$ & Down" & $-8,90 \%{ }^{c}$ & $-4,1777$ \\
\hline $0,+15$ & Up & $0,39 \%$ & 0,1140 & No & $0,61 \%$ & 0,2596 & Down" & $-3,79 \%$ & $-1,7782$ \\
\hline Alpha $=0 ;$ beta $=1$ & \multicolumn{3}{|c|}{ Lower dividend changes X.4.1 } & \multicolumn{3}{|c|}{ Normal dividend changes $X .4 .2$} & \multicolumn{3}{|c|}{ Higher dividend changes X.4.3 } \\
\hline Period & Trend & CAR & $t C A R$ & Trend & $C A R$ & $t C A R$ & Trend & $C A R$ & $t C A R$ \\
\hline$-15,+15$ & No & $3,61 \%$ & 0,6616 & $\mathbf{U p}^{\mathbf{b}}$ & $7,87 \%^{b}$ & 2,4306 & $U p^{b}$ & $10,78 \%^{c}$ & 2,8126 \\
\hline$-10,+10$ & No & $-0,27 \%$ & 0,0594 & $\mathbf{U p}^{\mathbf{b}}$ & $6,21 \%^{b}$ & 2,3314 & $\mathbf{U p}^{\mathrm{b}}$ & $7,42 \%$ & 1,9361 \\
\hline$-5,+5$ & Down & $-2,33 \%$ & $-0,7177$ & $\mathbf{U p}^{\mathbf{b}}$ & $4,59 \%^{b}$ & 2,3812 & $\mathbf{U} \mathbf{p}^{\mathbf{b}}$ & $4,99 \%$ & 2,1854 \\
\hline$-15, \quad 0$ & No & $-1,81 \%$ & $-0,4610$ & No & $1,53 \%$ & 0,6589 & No & $1,83 \%$ & 0,6683 \\
\hline $0,+15$ & $U_{p}^{b}$ & $5,42 \%$ & 1,3819 & $U p^{c}$ & $6,34 \%^{c}$ & 2,7243 & $U_{p^{b}}$ & $8,94 \%^{c}$ & 3,2486 \\
\hline
\end{tabular}

Jonckheere-Terpstra test

\begin{tabular}{cccc}
\hline Portfolio & $J^{*}$ value & Result \\
\hline $4.1-4.2-4.3$ & 1,64 & $C A R \quad 4.1=C A R \quad 4.2=C A R \quad 4.3$ \\
$X .4 .1-X .4 .2-\mathrm{X} .4 .3$ & $5,59^{\mathrm{c}}$ & $C A R \times .4 .1 \leqslant C A R \times .4 .2 \leqslant C A R \times .4 .3$ \\
\hline
\end{tabular}

- Significant at 0,10 level; ${ }^{b}$ Significant at 0,05 level; ${ }^{\mathrm{c}}$ Significant at 0,025 level

downward trend for the market model portfolio in the weeks before the announcement indicates that something might have gone wrong in the estimation of the market model parameters.

The downward picture seems to be consistent with the evidence reported in Dimson (1979) that shares trading on the average very frequently or very infrequently have ordinary least squares estimators asymptotically biased upward for alphas and downward for betas. It may also indicate that the market model is not appropriate for forecasting normal returns on the JSE.

The most striking feature of the response pattern is that the market reacts either positively or negatively to both good and bad news. This implies that the market is not able to distinguish good news from bad news or that the FB model is misspecified or that it is not appropriate for predicting dividend changes in the South African context.

Another alternative is that the market is not responding to the dividend information, but to the underlying earnings information which was simultaneously released.

\section{Naive classification scheme}

The results for the naive classification scheme (all shares) are summarized in Table 4 . The three market model portfolios generate a return which is lower than the market returns. The $C A R$ graph (Figure 4) shows a downward trend in the weeks preceding the

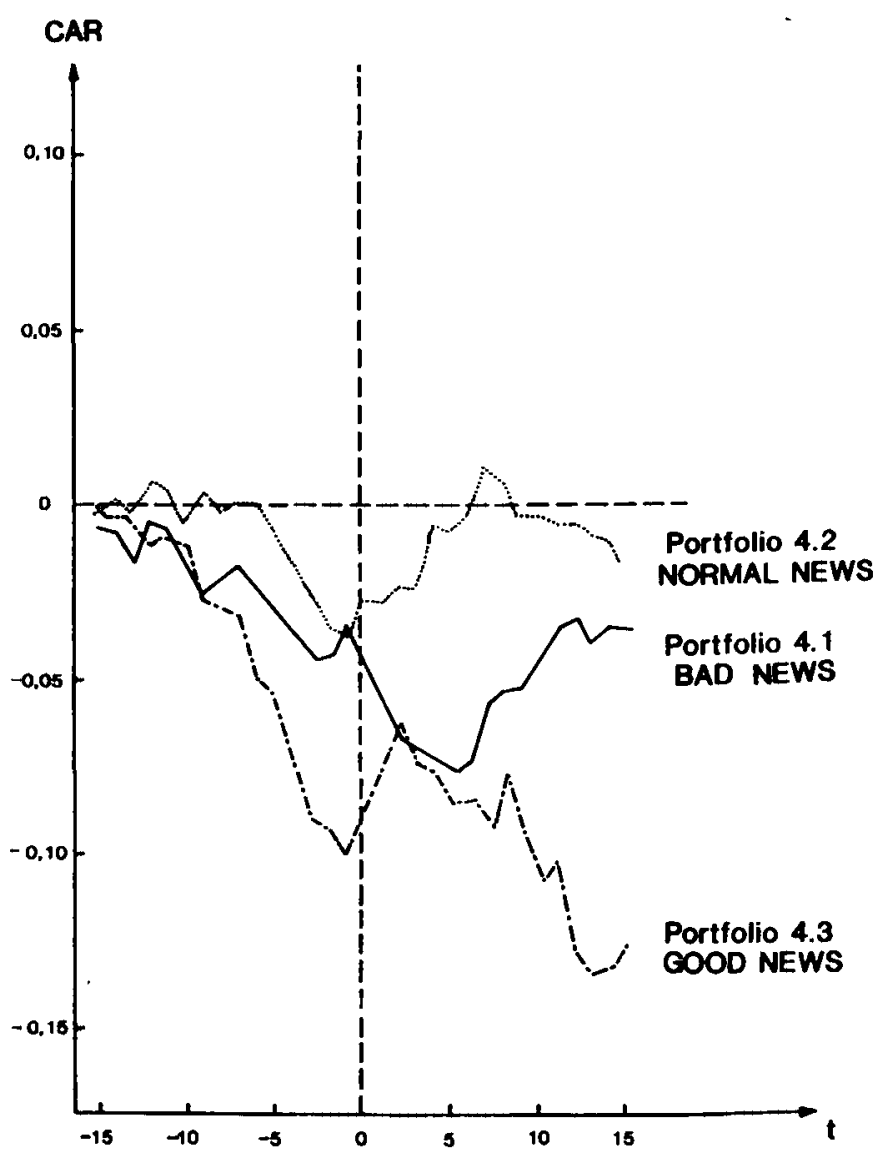

Figure 4 CAR graph - all shares - market model - relative dividend changes 
announcement. Again, the estimated market model coefficients seem to be biased. There is a positive market response in the weeks before the dividend announcement for the good news and the normal news portfolio, while there is a strong negative response to the bad news release.

Only the $C A R$ values for portfolio 4.3 are significantly different from zero. The Jonckheere-Terpstra test indicates that there is no significant difference among the returns generated by the market model portfolios.

Figure 5 shows that all portfolios do better than the market. The Jonckheere-Terpstra test demonstrates that there is a significant difference among the returns earned by the $X$ portfolios in the sense that the bad news portfolio yields the lowest return and the good news portfolio the highest.

The market responds negatively to the bad news announcements, extremely positively to the good news announcements and positively to the normal dividend changes.

In the particular case of the naive classification scheme it can be concluded that the market is sophisticated enough to distinguish among the different types of dividend information.

\section{Classification scheme based on the relationship between relative dividend changes and earnings changes}

Table 5 summarizes the results obtained from the $C A R$ analysis. Both the good news and the bad news portfolio

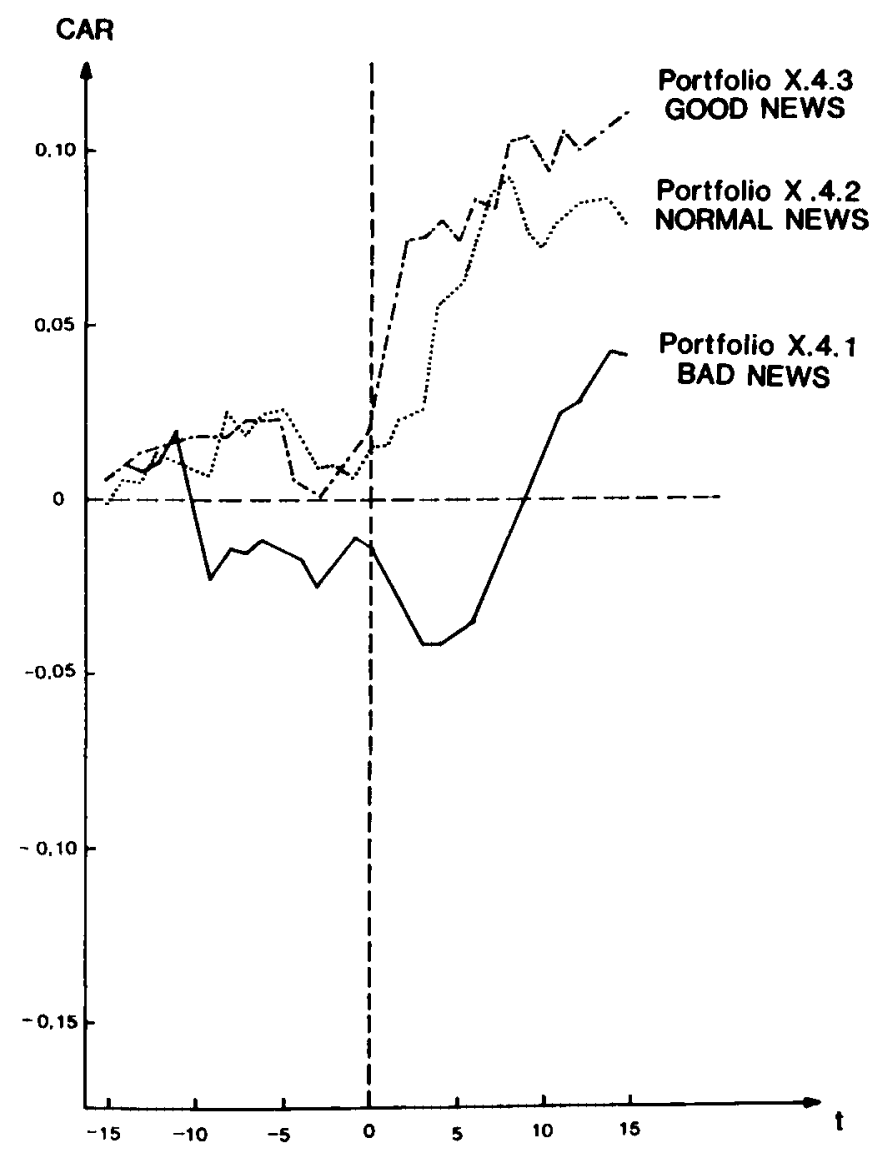

Figure $5 C A R$ graph - all shares - alpha $=0$, beta $=1-$ relative dividend changes
(Figure 6) yield a return which is lower than the return offered by the market portfolio. Again it is observed that the holder of a bad news portfolio is better off than the holder of a good news portfolio.

Both the good news and the bad news announcements are characterized by a downward trend, but in the weeks preceding the announcement there is a slight upward reaction. $C A R$ values are not significant for the bad news portfolio as indicated by panel $B$ in Table 5 .

Both $X$ portfolios yield a positive return (Figure 7). Panel $E$ indicates that the good news portfolio yields a higher return than the bad news portfolio. The market anticipates the good news announcement earlier than the bad news announcement.

It can be concluded that the results seem to be disturbed by biased market model coefficients. Both portfolios yield either a positive or a negative return depending on the methodology employed for calculating abnormal returns. The positive returns for both bad news portfolios might indicate that the market reacts to

Table 5 Classification scheme based on the relationship between relative changes in dividends and earnings

\begin{tabular}{|c|c|c|c|}
\hline Period & Trend & $C A R$ & I CAR \\
\hline \multicolumn{4}{|c|}{ A.Portfolio 7.1: Good news market model $-\mathrm{df}=33$} \\
\hline$-15,+15$ & Down' & $-9,41 \%^{c}$ & $-2,4490$ \\
\hline$-10,+10$ & Down' & $-7,27 \%$ b & $-2,2989$ \\
\hline$-5,+5$ & No & $-4,09 \%$ & $-1,7865$ \\
\hline$-15, \quad 0$ & Down ${ }^{6}$ & $-5,99 \%$ & $-2,1729$ \\
\hline $0,+15$ & Down ${ }^{\mathrm{b}}$ & $-3,41 \%$ & $-1,2346$ \\
\hline \multicolumn{4}{|c|}{ B.Portfolio 7.2: Bad news market model $-\mathrm{df}=34$} \\
\hline$-15,+15$ & Down' & $-3,80 \%$ & $-0,8530$ \\
\hline$-10,+10$ & No & $-3,62 \%$ & $-0,9877$ \\
\hline$-5,+5$ & No & $-2,60 \%$ & $-0,9815$ \\
\hline$-15, \quad 0$ & Down ${ }^{\mathbf{b}}$ & $-2,41 \%$ & $-0,7335$ \\
\hline $0,+15$ & No & $1,39 \%$ & 0,4338 \\
\hline \multicolumn{4}{|c|}{ C.Portfolio X.7.1: Good news - alpha $=0$, beta $=1-$ df $=33$} \\
\hline$-15,+15$ & $U_{p}^{b}$ & $10,82 \%^{c}$ & 2,7787 \\
\hline$-10,+10$ & $\mathrm{Up}^{b}$ & $7,74 \% \mathrm{c}$ & 6,4891 \\
\hline$-5,+5$ & $\mathrm{Up}^{\mathrm{b}}$ & $4,80 \%$ b & 2,0701 \\
\hline$-15, \quad 0$ & $U_{p}^{b}$ & $4,94 \%$ & 1,7679 \\
\hline $0,+15$ & $\mathrm{Up}^{\mathrm{b}}$ & $5,87 \%$ b & 2,0999 \\
\hline \multicolumn{4}{|c|}{ D.Portfolio X.7.2: Bad news - alpha $=0$, beta $=1-\mathrm{df}=34$} \\
\hline$-15,+15$ & $\mathbf{U p}_{\mathrm{p}}^{\mathrm{b}}$ & $9,53 \%{ }^{c}$ & 2,8395 \\
\hline$-10,+10$ & $\mathrm{Up}^{\mathrm{b}}$ & $5,03 \%$ & 1,8214 \\
\hline$-5,+5$ & $U_{p^{b}}^{b}$ & $6,05 \%{ }^{c}$ & 3,0257 \\
\hline$-15, \quad 0$ & No & $0,75 \%$ & 0,3089 \\
\hline $0,+15$ & $U_{p}^{b}$ & $8,79 \%{ }^{c}$ & 3,6434 \\
\hline Portfolio & & & esult \\
\hline \multicolumn{4}{|c|}{ E.Jonckheere-Terpstra test } \\
\hline $7.1-7.2$ & & & $\leqslant C A R 7.2$ \\
\hline X.7.1-X.7.2 & & $C A$ & $\geqslant C A R \times .7 .2$ \\
\hline
\end{tabular}

" Significant at 0,10 level; $^{\circ}$ Significant at 0,05 level

'Significant at 0,025 level 


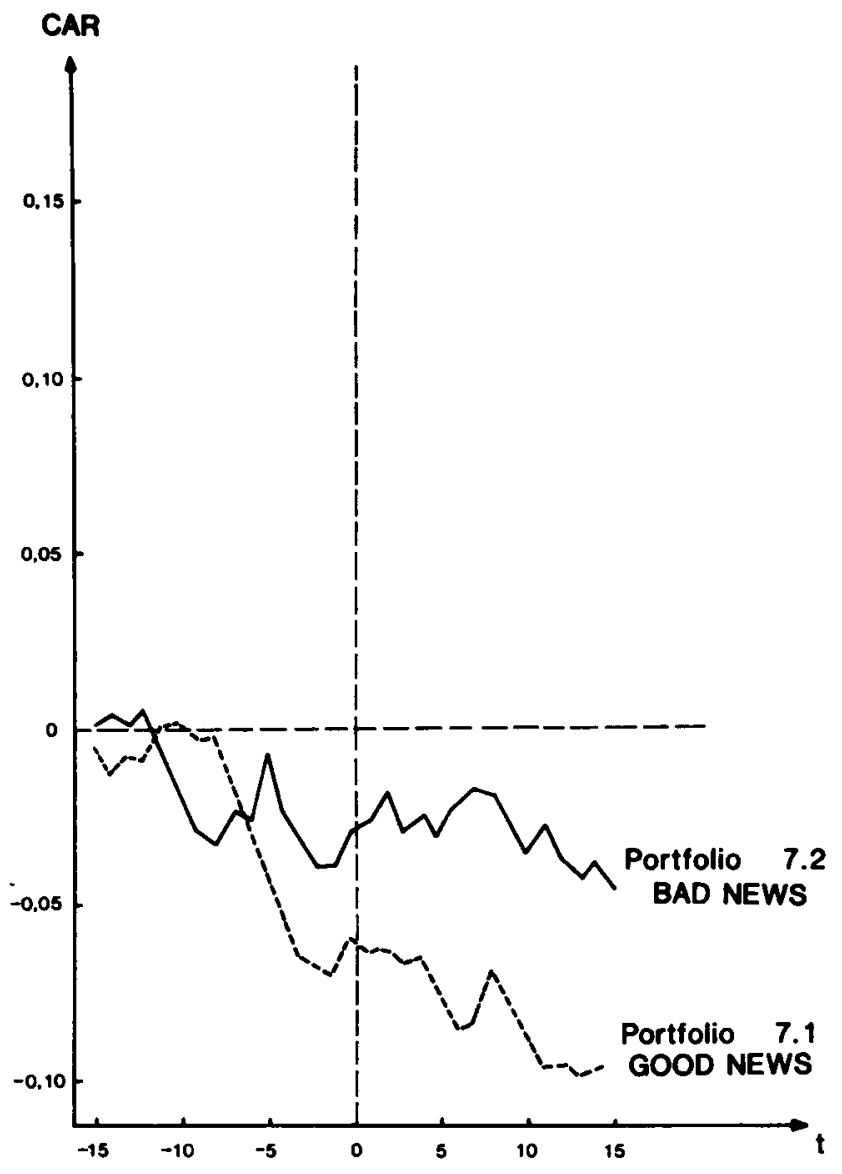

Figure 6 CAR graph - all shares - market model relationship between relative dividend changes and earnings changes

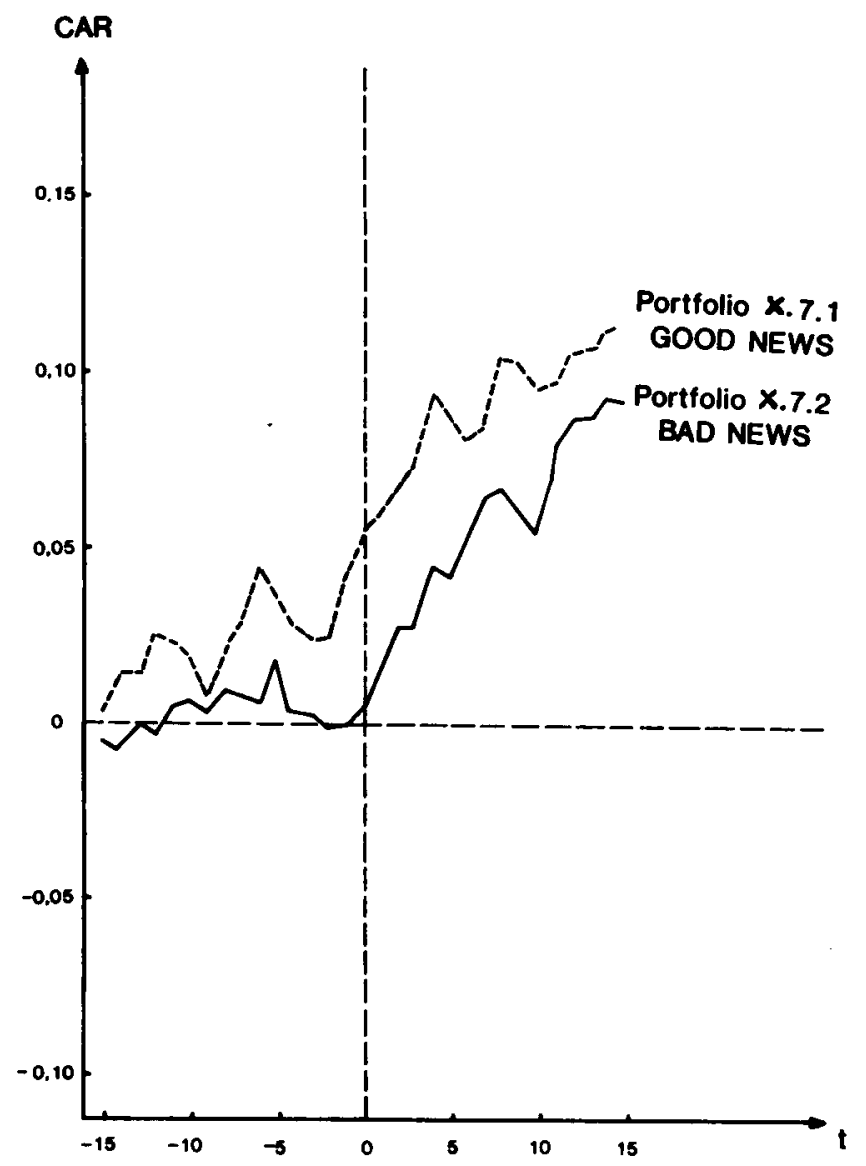

Figure $7 C A R$ graph - all shares - alpha $=0$, beta $=1-$ relationship between relative dividend changes and earnings changes the underlying earnings announcement, an issue which may be cleared up by the two-stage regression analysis.

\section{Two-stage regression approach}

For the all shares portfolio it can be concluded that all $\gamma_{1}$ values are significantly different from zero, at least at the significance level of $10 \%$ (Table 6). This implies that dividends provide information over and above the information provided by earnings. Two out of the three $\gamma_{2}$ values are significantly different from zero, which indicates that earnings provide information incremental to the information provided by dividends.

As both the $\gamma_{1}$ and $\gamma_{2}$ values are significantly different from zero, it can be concluded that earnings and dividends are surrogates in terms of information value. This implies that South African investors only need dividend or earnings announcements in order to revise their expectations concerning the value of the company. In order to obtain confirmation or to weaken this conclusion, different portfolios, according to the classification schemes discussed above, were analysed.

As can be deduced from Table 6, the two-stage regression analysis does not clear up the issue as to whether dividends convey important information to the market or not. In most cases however the quality of the second stage regression is very low which makes the results of the analysis at least questionable. It seems that the standard used for measuring returns influences the

Table 6 Summary of two-stage regression analysis results

\begin{tabular}{|c|c|c|c|}
\hline Portfolio & Return & $\gamma_{1}$ value & $\gamma_{2}$ value \\
\hline \multirow[t]{3}{*}{ All shares } & $P_{i, \mathrm{~s}}$ & Significant & Significant \\
\hline & $\Delta C A R_{i, t}$ & Significant & Insignificant \\
\hline & $\triangle X C A R_{i, t}$ & Significant & Insignificant \\
\hline \multirow[t]{3}{*}{ Positive FB residuals } & $P_{i, t}$ & Insignificant & Significant \\
\hline & $\Delta C A R_{i, r}$ & Insignificant & Insignificant \\
\hline & $\Delta X C A R_{i, t}$ & Insignificant & Insignificant \\
\hline \multirow[t]{3}{*}{ Negative FB residuals } & $P_{i, r}$ & Insignificant & Insignificant \\
\hline & $\Delta C A R_{i, 1}$ & Insignificant & Insignificant \\
\hline & $\triangle X C A R_{i, \iota}$ & Insignificant & Insignificant \\
\hline \multirow[t]{3}{*}{ Small dividend changes } & $P_{i, t}$ & Insignificant & Insignificant \\
\hline & $\Delta C A R_{i, \ell}$ & Insignificant & Insignificant \\
\hline & $\triangle X C A R_{i, 1}$ & Insignificant & Insignificant \\
\hline \multirow[t]{3}{*}{ Normal dividend changes } & s $P_{i, l}$ & Insignificant & Insignificant \\
\hline & $\Delta C A R_{i, 1}$ & Insignificant & Insignificant \\
\hline & $\triangle X C A R_{i, t}$ & Insignificant & Insignificant \\
\hline \multirow[t]{3}{*}{ Large dividend changes } & $\boldsymbol{P}_{i, r}$ & Insignificant & Insignificant \\
\hline & $\Delta C A R_{i, t}$ & Insignificant & Insignificant \\
\hline & $\triangle X C A R_{i, 1}$ & Insignificant & Insignificant \\
\hline \multirow[t]{3}{*}{$\triangle D I V I D I V>\triangle E P S / E P S$} & $P_{i, \ell}$ & Insignificant & Insignificant \\
\hline & $\triangle C A R_{i, 1}$ & Significant & Significant \\
\hline & $\triangle X C A R_{i, 1}$ & Significant & Insignificant \\
\hline \multirow[t]{3}{*}{$\triangle D I V I D I V<\triangle E P S / E P S$} & $P_{i, t}$ & Insignificant & Insignificant \\
\hline & $\Delta C A R_{i, t}$ & Insignificant & Significant \\
\hline & $\triangle X C A R_{i, r}$ & Insignificant & Significant \\
\hline
\end{tabular}

Significant only at the 0,10 level 
results. Quite a few times it can be concluded that neither dividend nor earnings announcements convey information to the market or that the channels for communicating information to the market are not appropriate.

\section{Conclusions}

This study was undertaken in. order to determine whether dividend announcements convey significant information for the investment public of the JSE. The results obtained from the $C A R$ approach can be summarized as follows.

- In most cases a significant positive reaction was recorded around the announcement week for both the goods news and the bad news portfolios. However, abnormal returns were generally not significantly different from zero.

- It seems that the market is not sophisticated enough to distinguish between good and bad news as both portfolios yield either positive or negative returns relative to market returns. In quite a few cases investors holding a bad news portfolio were better off than holders of a good news portfolio.

- The response pattern of the market to dividend announcements can be described as 'coincident response' (Stern, 1977: 44). It implies that the change in share price depends on the release of information. After the announcement share prices rise to their new intrinsic values. According to Stern this pattern may be attributable to insufficient investor sophistication, but it may also be caused by an inappropriate financial superstructure which does not allow an efficient transfer of information from companies to investors.

- It was noticed that most abnormal returns were highly significant around week +7 . This might indicate some kind of L.D.R. trading.

- The results obtained from this study certainly do not invalidate Knight's results (1983) on the information content of earnings as dividend information is unlikely to be significant enough to confound the interpretation of earnings information.

- The results do not invalidate the efficient market hypothesis as traders on dividend information are not able to generate significant returns which are consistently different from market returns. This conclusion is dependent on the models and methodology used in the study.

The results are subject to the deficiencies pointed at previously, such as the bias introduced in estimating market model parameters, classification schemes which are unable to separate confounding dividend and earnings information etc. ... The two-stage regression analysis was unable to solve the issue of confounding information effects. Further research is needed for refining the methodology of announcement studies in order to be able to give a conclusive answer to the problem of the information content of dividends.

\section{Acknowledgement}

Financial assistance by the Human Sciences Research Council is gratefully acknowledged.

\section{References}

Affleck-Graves, J.F. 1983. Unpublished class notes, University of Stellenbosch Business School.

Beaver, W.H., Griffin, P.A. \& Landsman, W.R. 1982. The incremental information content of replacement cost earnings. J. Accoun. Econ., vol. 4, 15-39.

Brown, S.J. \& Warner, J.B. 1980. Measuring security price performance. J. Finan. Econ., vol. 8, 205-258.

Daniel, W. 1978. Applied non-parametric statistics. Boston, Mass.: Houghton-Mifflin.

De Villiers, J.U. 1980. Handleiding vir die berekening van die risiko-koëffisiënte van aandele. Unpublished technical report, University of Stellenbosch, 105p.

Dimson, E. 1979. Risk measurement when shares are subject to infrequent trading. J. Finan. Econ., 197-226.

Du Plessis, D.P. 1984. The incremental information content of AC 201 inflation-adjusted data. Unpublished doctoral thesis, University of Stellenbosch, 298p.

Fama, E.F. \& Babiak, H. 1968. Dividend policy: an empirical analysis. J. Am. Stat. Assoc., vol. 63, 1132-1161.

Fama, E.F. 1970. Efficient capital markets, a review of theory and empirical work. J. Fin., vol. 25, 383-417.

Gujarati, D. 1978. Basic Econometrics. Singapore, McGraw-Hill, 462p.

Jaffe, J.F. 1974. The effect of regulation changes on inside trading. Bell J. Econ., vol. 5, 93-121.

Knight, R.F. 1983. The association between published accounting data and the behaviour of share prices. Unpublished doctoral thesis, University of Cape Town, 400 p.

Knight, R.F. \& Affleck-Graves, J.F. 1984. The information content of dividends incremental to the information content of earnings, The South African experience. University of Cape Town, 48p.

Kwan, C.C.Y 1981. Efficient market tests of the informational content of dividend announcements: critique and extension. J. Financ. Quant. Anal., vol. 16, 193-206.

Pettit, R.R. 1972. Dividend announcements, security performance, and capital market efficiency. J. Fin., vol. 28, 993-1007.

Raes, R. 1984. Evaluation of portfolio performance and security recommendations, methodology and application. Unpublished research paper. Universitaire Faculteiten Sint-Ignatius Antwerpen, 28p.

Scholes, M. \& Williams, J. 1977. Estimating betas from non-synchronous data. J. Fin. Econ., vol.4, 309-327.

Stern, J. 1977. Analytical methods in financial planning. 3rd ed. New York, The Chase Manhattan Bank, 81p.

Watts, R. 1973. The information content of dividends. J. Bus., vol. $46,191-211$. 